\title{
Ilmenite Inclusion: A Solution towards Solid Sagging for Hematite-Based Invert Emulsion Mud
}

\author{
Salem Basfar $(\mathbb{D}$, Ashraf Ahmed $(\mathbb{D}$, and Salaheldin Elkatatny $(\mathbb{D}$ \\ College of Petroleum Engineering and Geosciences, King Fahd University of Petroleum \& Minerals, Dhahran 31261, Saudi Arabia \\ Correspondence should be addressed to Salaheldin Elkatatny; elkatatny@kfupm.edu.sa
}

Received 2 November 2021; Revised 1 December 2021; Accepted 15 December 2021; Published 6 January 2022

Academic Editor: Mohammad Sarmadivaleh

Copyright (C) 2022 Salem Basfar et al. This is an open access article distributed under the Creative Commons Attribution License, which permits unrestricted use, distribution, and reproduction in any medium, provided the original work is properly cited.

\begin{abstract}
The sagging tendency of hematite in drilling mud is a common challenge occurring at high-pressure and high-temperature (HP/ HT) applications. This work studies the performance of hematite-based invert emulsion mud for HP/HT conditions and provides a solution to prevent the hematite settlement using a combination of ilmenite with hematite. Practical mud formulation was utilized over a range of ilmenite/hematite ratios $(0 / 100,20 / 80,40 / 60$, and 50/50\%) to study sagging behaviour. From the sag tests, the optimum combination proportion was determined. Thereafter, the density, emulsion stability, rheological and viscoelastic properties, and filtration conduct for the formulated mud were evaluated. The experiments were conditioned as per the standards of the American Petroleum Institute. The obtained results of sagging experiments indicated that including 50\% of ilmenite mitigated the hematite settling and reduced the sag tendency towards the safe range. A slight drop (4\%) in mud weight was noticed upon adding the ilmenite, whereas the emulsion stability was enhanced from 551 to 574 volts with the $50 \%$ ilmenite content. The rheology and viscoelasticity measurements showed that 50/50\% combination improved the yield point (YP) by $50 \%$ with a trivial $1 \mathrm{cP}$ increment on plastic viscosity (PV), hence enhancing the YP/PV ratio by $46 \%$. Also, the gelling strength was enhanced resulting in flat rheology and better gel structure. The filtration behaviour of $50 \%$ ilmenite mud was improved compared to blank hematite as it resulted in 21,15 , and $17 \%$ reduction on the filtrated volume, filter cake weight, and thickness, respectively. This study provides a solution for hematite sagging issue at HP/HT using combined weighting agents, which contributes to enhancing the mud stability and avoiding several well control issues and related operational and technical challenges that eventually will economize the drilling cost and time.
\end{abstract}

\section{Introduction}

Generally, two types of drilling muds are used (i.e., aqueousbased and nonaqueous-based mud) [1-4]. The aqueousbased mud is widely applied but with considerable challenges in hostile conditions such as water-sensitive and high-pressure and high-temperature (HP/HT) formations, where the nonaqueous-based mud has a preferred technical performance but with environmental concerns $[3,5]$. Hence, the nonaqueous invert emulsion mud is practically introduced to support the higher technical criteria and satisfy the environmental regulations, which result in integrating the practical benefits of both aqueous and nonaqueousbased muds $[3,6]$. The efficient control of the hydrostatic and formation pressures in drilling operations is the primary function of drilling muds. This can be achieved by maintaining the fluid density using proper weighting agents.

Drilling in HP/HT conditions requires using higher density mud [7]; however, mud stability and rheology controlling are the main associated technical issues. Breakdown of drilling fluid stability usually occurs by solid settlement (sagging) of weighting agents. Many factors affect this sagging phenomenon such as gravity, drilling parameters, and mud properties which results in significant variation in mud weight, deterioration of mud performance, and several well control challenges [8-11]. These technical and operational issues necessitate a choice of efficient weighting agents to ensure mud consistency.

Barite $\left(\mathrm{BaSO}_{4}\right)$ is widely used to densify the drilling mud with severe associated problems at $\mathrm{HP} / \mathrm{HT}$ applications [12-14]. Since barite has a relatively low specific gravity, 
high solid content is required to obtain the desired density, which results in settlement of solid particles, more viscous fluid, higher equivalent circulation density, and exaggerated torque. The resulting inconsistent drilling fluid properties will eventually lead to wellbore instability, pipe sticking, circulation losses, and significant increase in drilling costs [15-18]. Accordingly, the industry seeks for practical solutions to mitigate these serious issues using alternative applicable weighting materials that provide high-density mud such as hematite, ilmenite, and Micromax [19-25].

Hematite $\left(\mathrm{Fe}_{2} \mathrm{O}_{3}\right)$ is electrically conductive with specific gravity of $4.9-5.3 \mathrm{~g} / \mathrm{cm}^{3}$. It is known as an absorbent, blasting, and adhesive agent. Hematite was firstly proposed as a weighting agent by Haaland et al. [26]; then, its utilization in drilling fluids grows significantly showing lower solid content, significant ROP improvement, acid solubility, and low toxicity [19-23]. The relatively high abrasiveness of hematite is reduced by micronizing its particles [27], which helps in improving the filtration and rheology performance as well [28-37]. However, hematite sagging was still encountered in HP/HT wells [24, 38-41].

Titanium-iron oxide mineral $\left(\mathrm{FeTiO}_{3}\right)$, known as ilmenite, has specific gravity of $4.5-5.1 \mathrm{~g} / \mathrm{cm}^{3}$, lower abrasiveness than hematite, and acid solubility. Ilmenite is successfully utilized as a weighting material [24, 28, 42]. Several studies addressed using a combination of weighting materials in various concentrations, and mixture utilization has been extended to mitigate the associated issues and yield better fluid stability which improves the efficiency of drilling operations [7, 17, 40, 41, 43, 44]. The combination of ilmenite and hematite for aqueous-based mud showed successful mitigation of solid sagging with competent mud properties [41].

This study is aimed at providing a solution for preventing the settling of hematite particles in invert emulsion mud at HP/HT applications and improving the mud suspension capacity by employing a range of ilmenite/hematite combination ratios $(0 / 100,20 / 80,40 / 60$, and 50/50\%). From the sag tests, the optimal combination proportion was identified. Then, the key mud characteristics, represented by the mud density, emulsion stability, rheology, viscoelasticity, and filtration behaviour were addressed for the recommended formulated mud.

\section{Materials and Experiments}

2.1. Materials. Several invert emulsion mud samples were prepared using a practical field formulation. In these recipes, for each $350 \mathrm{~cm}^{3}$ of mud, $172 \mathrm{~cm}^{3}$ of diesel was used as a continuous phase. Invermul and Ez-mul with amounts of $11 \mathrm{~cm}^{3}$ and $4 \mathrm{~cm}^{3}$ were added as primary and secondary emulsifiers, respectively. These emulsifiers were mixed for 10 minutes each. The alkalinity was controlled using $6 \mathrm{~g}$ of lime, and $7 \mathrm{~g}$ of duratone was added to control the fluid losses. The internal phase in the formula was represented by $50 \mathrm{~cm}^{3}$ of water mixed with $32 \mathrm{~g}$ of calcium chloride $\left(\mathrm{CaCl}_{2}\right)$ to ensure the shale inhibition capability. Then, $10 \mathrm{~g}$ of geltone viscosifier was added. $30 \mathrm{~g}$ of calcium carbonate $\left(\mathrm{CaCO}_{3}\right)$ was added which is the most common bridging agent in drilling fluids. Lastly, $300 \mathrm{~g}$ of combined ilmenite/ hematite weighting materials in different ratios $(0 / 100 \%$, $20 / 80 \%, 40 / 60$, and $50 / 50 \%)$ was added. To ensure the proper function of the mud components, the additives were added sequentially and mixed for 10 minutes each additive except the viscosifier and weighting materials mixed for 20 minutes. The additives used to prepare these mud recipes were obtained from the drilling fluid service provider.

2.2. Experiments. Firstly, the Helos laser particle size analyzer, JEOL JSM-5900LV scanning electron microscope (SEM), and M4 Tornado X-ray fluorescence (XRF) were utilized to study the mineralogical features of both hematite and ilmenite.

Then, the tendency of solid settlement with different concentrations of ilmenite was addressed by performing the sagging tests at static and dynamic conditions. Thereafter, the optimal mixture of ilmenite/hematite that led to settling mitigation was determined. The static test was performed at vertical and $45^{\circ}$ deviated positions as the sag issue is practiced in both vertical and slanted wells. A pressure of $500 \mathrm{psi}$ and temperature of $350^{\circ} \mathrm{F}$ were applied on muds that aged in the Ofite aging cell for 24 hours. The static sag factor was determined by identifying the $10 \mathrm{~cm}^{3}$ fluid weights from the top and bottom parts of the cell ( $W_{\text {top }}$ and $\left.W_{\text {bottom }}\right)$ and using Equation (1) [45]:

$$
\text { Sag factor }=\frac{W_{\text {bottom }}}{W_{\text {bottom }}+W_{\text {top }}} .
$$

For the dynamic sag test, a viscometer (model 900) was used to rotate the mud samples with $100 \mathrm{rpm}$ for 30 minutes under $150^{\circ} \mathrm{F}$. The dynamic sagging magnitude was determined by calculating the viscometer sag shoe test (VSST) value in ppg using Equation (2) [46], where $W_{\text {before }}$ and $W_{\text {after }}$ are the weights in grams of $10 \mathrm{~cm}^{3}$ fluid from the bottom of the cup before and after rotation:

$$
\operatorname{VSST}=0.834 \times\left(W_{\text {after }}-W_{\text {before }}\right)
$$

Since several technical and operational problems in well drilling are mainly affected by drilling fluid properties, the key mud features were evaluated including the mud density, emulsion stability, rheology, viscoelasticity, and filtration properties.

The mud density and emulsion stability were measured using the mud balance and electrical stability meter at ambient conditions.

The Ofite HP/HT viscometer was used to carry out the rheology tests at elevated temperature $\left(350^{\circ} \mathrm{F}\right)$ to estimate the rheological properties of the optimum recommended combination of hematite and ilmenite (i.e., plastic viscosity, yield point, and gel strengths). Shear stresses corresponding to several shear rates $(600,300,200,100,6$, and $3 \mathrm{rpm})$ were recorded for each mud sample; then, the plastic viscosity was determined from the difference between readings at 600 and $300 \mathrm{rpm}$, while the yield point was identified by subtracting the calculated plastic viscosity from the stress reading at $300 \mathrm{rpm}$. The gel strengths were measured at the lowest 


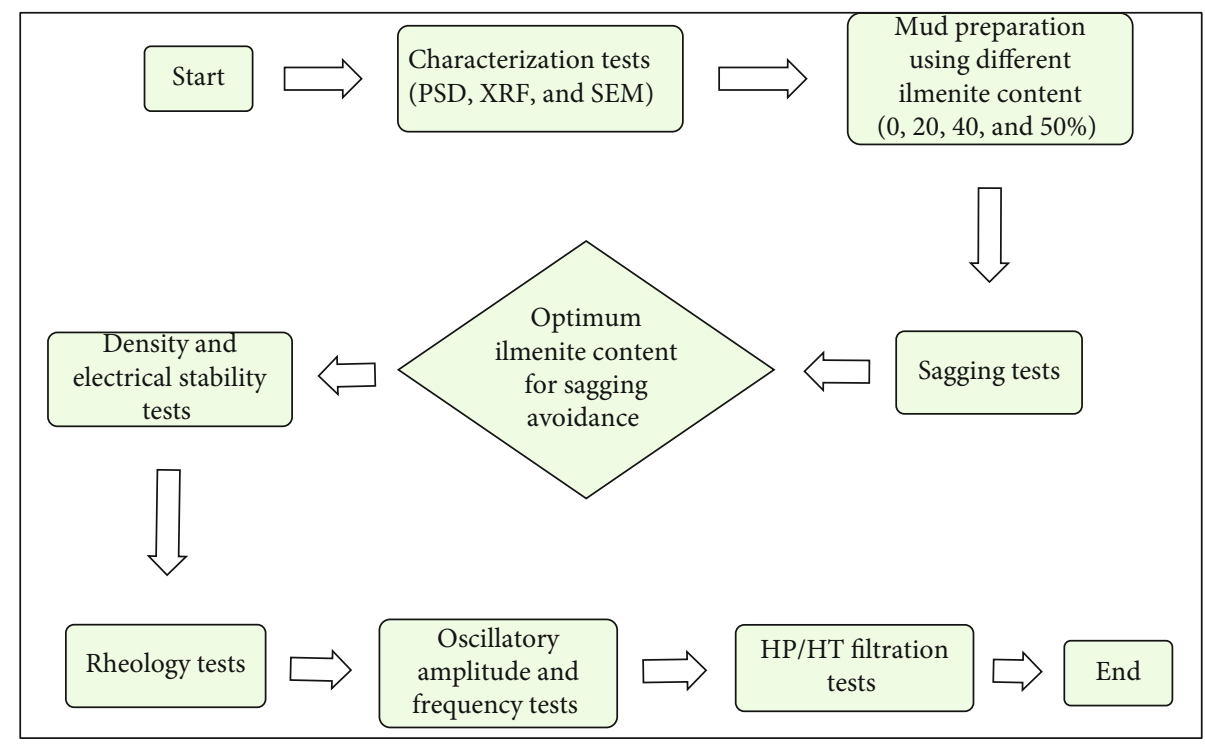

FigURE 1: Experimental workflow.
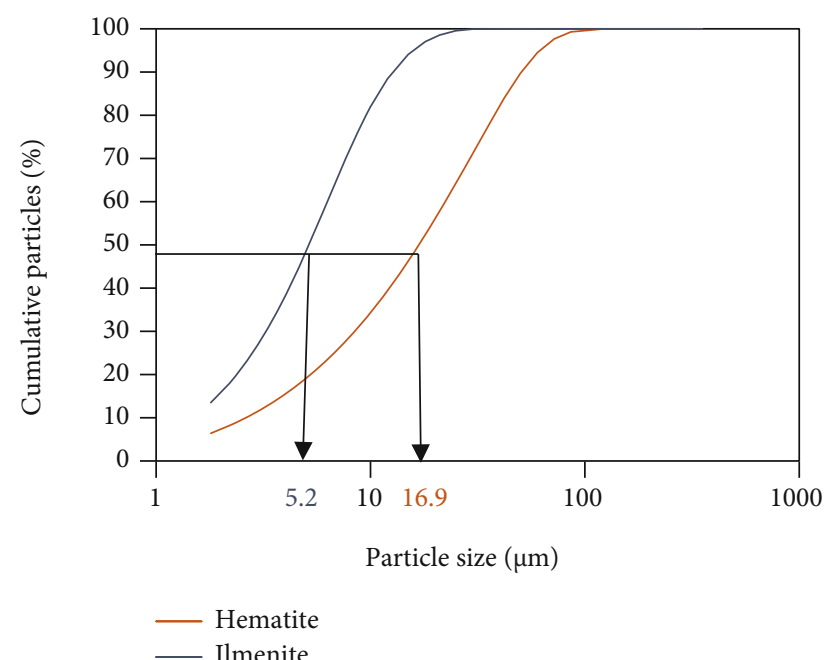

FIGURE 2: Particle size distribution (PSD) for hematite and ilmenite.

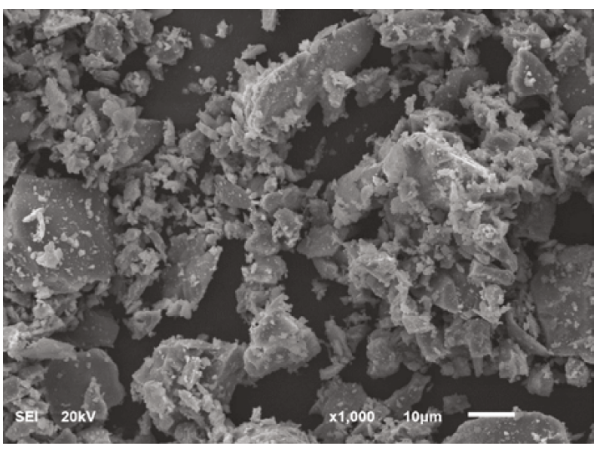

(a)

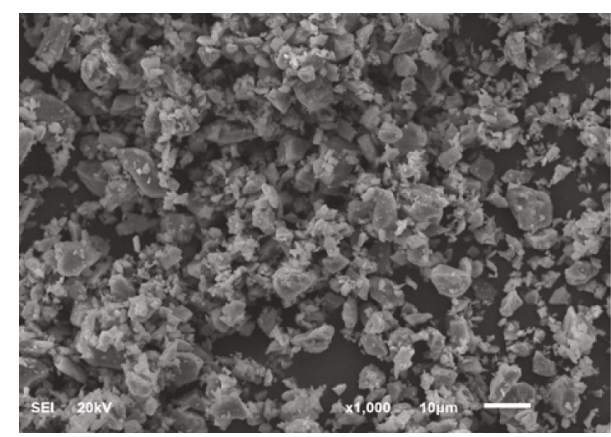

(b)

FIGURE 3: SEM images for (a) hematite and (b) ilmenite. 


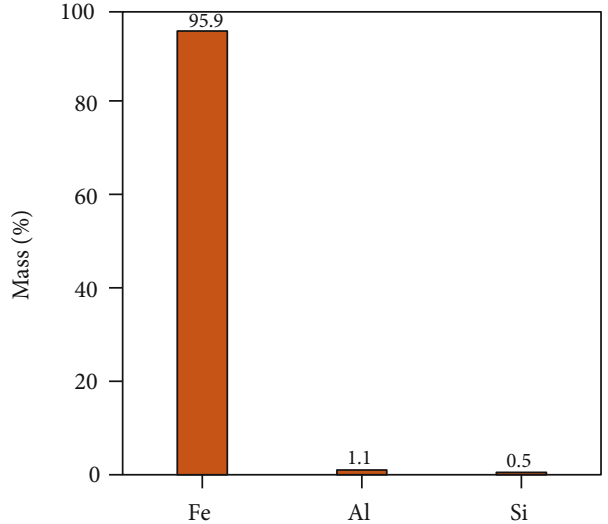

(a)

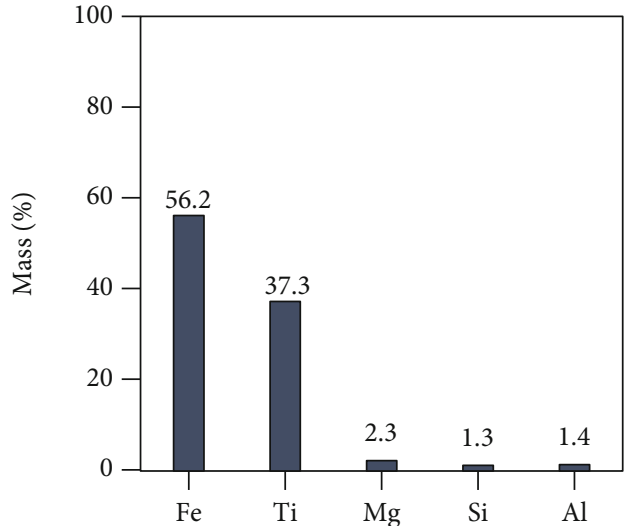

(b)

FIGURE 4: The elemental composition is derived from an XRF measurement on (a) hematite and (b) ilmenite.

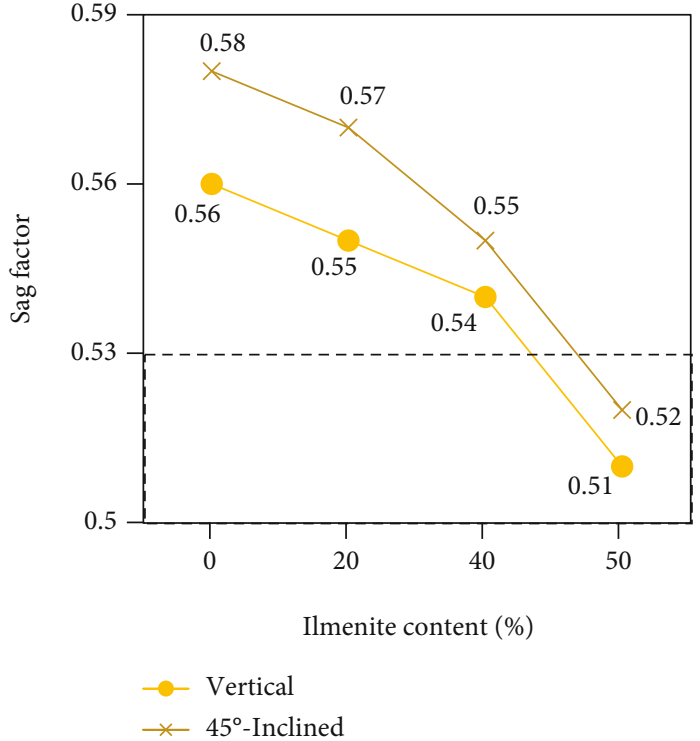

(a)

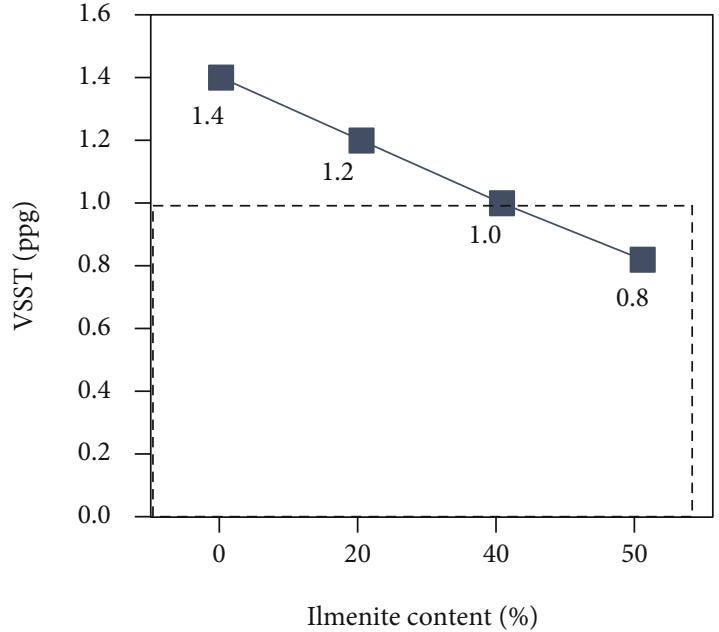

(b)

Figure 5: Results of sag tests under (a) static conditions at $350^{\circ} \mathrm{F}$ and (b) dynamic conditions at $150^{\circ} \mathrm{F}$.

shear rate after keeping the fluid at static conditions for 10 seconds and 10 and 30 minutes.

The viscoelastic properties like storage $\left(G^{\prime}\right)$ and loss moduli $\left(G^{\prime \prime}\right)$ for the prepared muds were studied by performing the oscillatory amplitude and frequency tests, using the Anton-Paar rheometer (MCR 702), to investigate the elasticity of the inner structure. In the amplitude test, $0.01 \%-100 \%$ range of shear strain values were used at a fixed frequency of $10 \mathrm{rad} / \mathrm{s}$ for defining the linear viscoelastic range, whereas the frequency test was carried out at various frequencies ranging $0.1-100 \mathrm{rad} / \mathrm{s}$ and fixed shear strain value.

The filtration experiment was conducted, using Ofite HP/ HT filter press (model MB), to study the filtration behaviour of the optimum ilmenite/hematite mixture. The test was performed using a $50 \mu \mathrm{m}$ ceramic disc as filtration media under differential pressure of $500 \mathrm{psi}$ and temperature of $350^{\circ} \mathrm{F}$. The

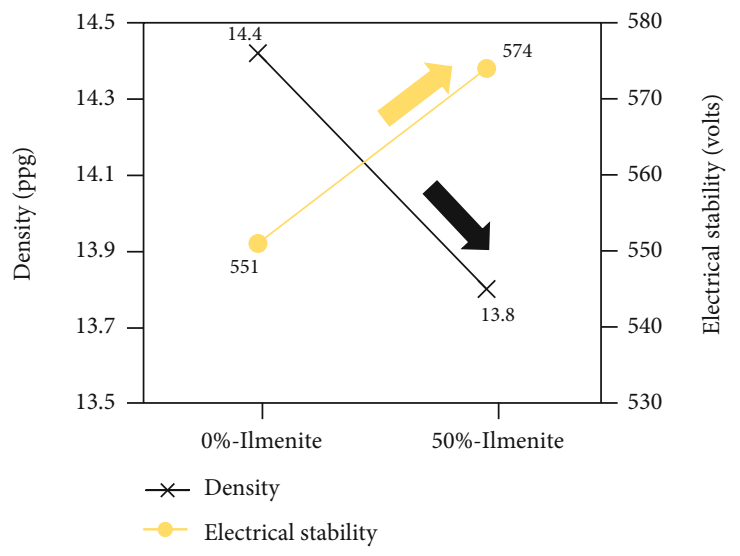

Figure 6: Mud density and electrical stability for base hematite and $50 \%$ ilmenite muds at ambient condition. 


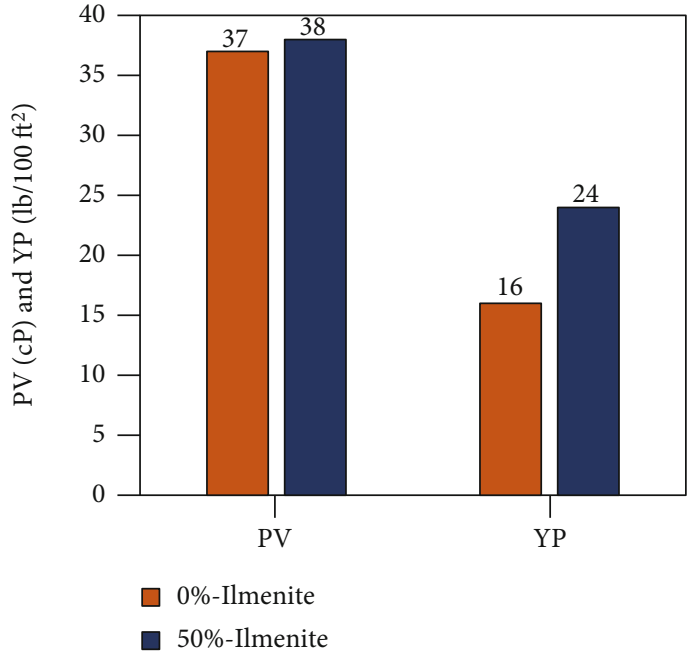

(a)

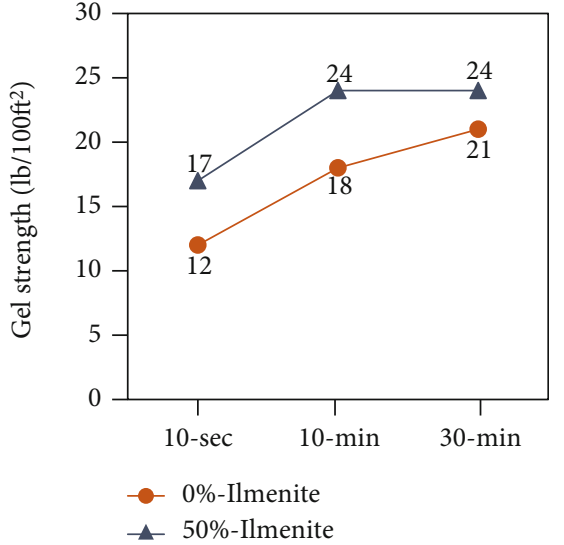

(b)

Figure 7: Effects of adding 50\% ilmenite on rheology at $350^{\circ} \mathrm{F}$.

filtrated volume was observed for 30 minutes, and the thickness and weight of the filter cake were measured.

The experimental workflow of this study is summarized in Figure 1.

\section{Results and Discussion}

3.1. Weighting Material Characterization. Recently, the utilization of hematite in drilling fluids grows significantly showing competent performance but with sagging issues at elevated temperature and relatively high abrasiveness. While ilmenite is successfully utilized as weighting material with lower abrasiveness than hematite, it is relatively more expensive. Accordingly, a combination of ilmenite and hematite was considered in this study to get the most benefits of each weighting material and minimize their technical and economic concerns. The characterization of both materials indicated their features as follows.

The particle size analyzer showed that ilmenite has less average particle size $\left(D_{50}\right)$ of $5.2 \mu \mathrm{m}$ than $16.9 \mu \mathrm{m}$ for hematite particles (Figure 2). This tiny particle size helps to minimize equipment erosion, because the abrasiveness of weighting materials increases with its particle size [47].

The large crystal structure and sharp-edged particles of hematite, as depicted in Figure 3, contribute to its abrasiveness. On the other hand, the SEM images showed that ilmenite has smaller and uniform particle sizes, which will help to mitigate the hematite abrasiveness issue after combination.

The chemical elemental composition for ilmenite and hematite was analyzed using XRF. The results presented that $56.2 \%$ iron, $37.3 \%$ titanium, and small percentages of magnesium, aluminium, and silicon are the main elements constituting ilmenite, whereas iron with $95.9 \%$ predominates in hematite composition with few contents of aluminium and silicon (Figure 4).
3.2. Sagging Tendency. The results from sag tests asserted the settling problem of hematite mud at HP/HT, since the static sagging factors were 0.56 and 0.58 in vertical and inclined positions, respectively (Figure 5(a)), whereas the recommended range is $0.50-0.53$ [48]. At dynamic condition, the obtained viscometer sag shoe test value (VSST) was $1.4 \mathrm{ppg}$ compared to the safe values of less than $1.0 \mathrm{ppg}$ [46], as depicted in Figure 5(b).

Including ilmenite in several ratios (0, 20, 40, and 50\%) resulted in fluids with lower sag tendency showing minimum solid settling and avoiding density inconsistency. The addition of $50 \%$ ilmenite brought the mud well within the recommended static sagging factor ranges at vertical and inclined situations $(0.51$ and 0.52$)$, while $0.8 \mathrm{ppg}$ was the VSST value from the dynamic test, as shown in Figure 5. The enhancement of the sagging performance is attributed to the surface charge, colloidal stability, and particle shape and size of ilmenite [16, 17, 42, 43].

In practice, hematite sagging leads to several well control issues such as wellbore instability, pipe sticking, and loss of circulation due to the broad variance in mud properties; therefore, mitigating these problems will minimize the nonproductive time and reduce the drilling cost. Moreover, compared to hematite, ilmenite has less sagging tendency, but with relatively higher cost, so combining ilmenite with hematite can enhance the mud stability and defeat the relatively higher cost of ilmenite. Since the 50/50\% ilmenite/ hematite mixture satisfies the necessities pertaining to sag performance and cost optimization, this mixing percentage was considered for further investigation to address its impact on the key mud properties.

3.3. Density and Electrical Stability Tests. Combining 50\% of ilmenite with hematite slightly reduces the mud density from $14.4 \mathrm{ppg}$ for the base mud to $13.8 \mathrm{ppg}$ because ilmenite has relatively less specific gravity. Practically, hematite 


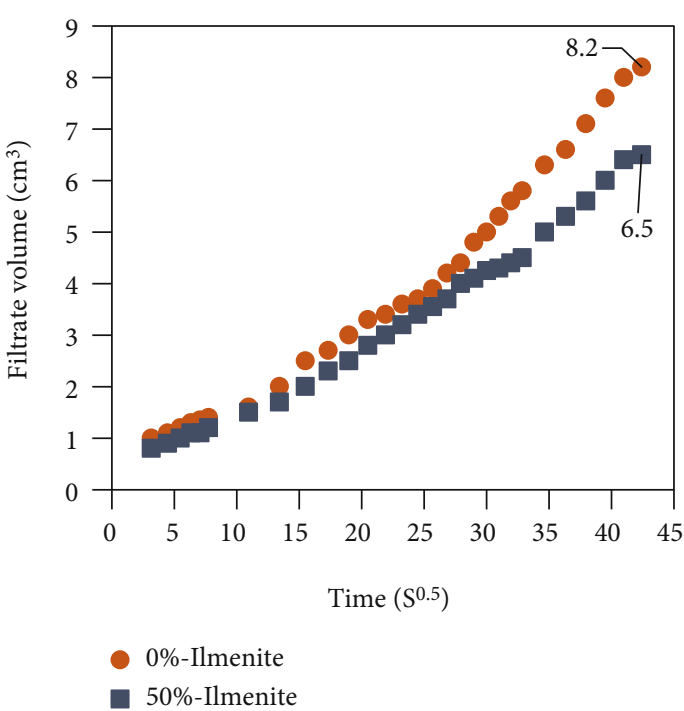

(a)

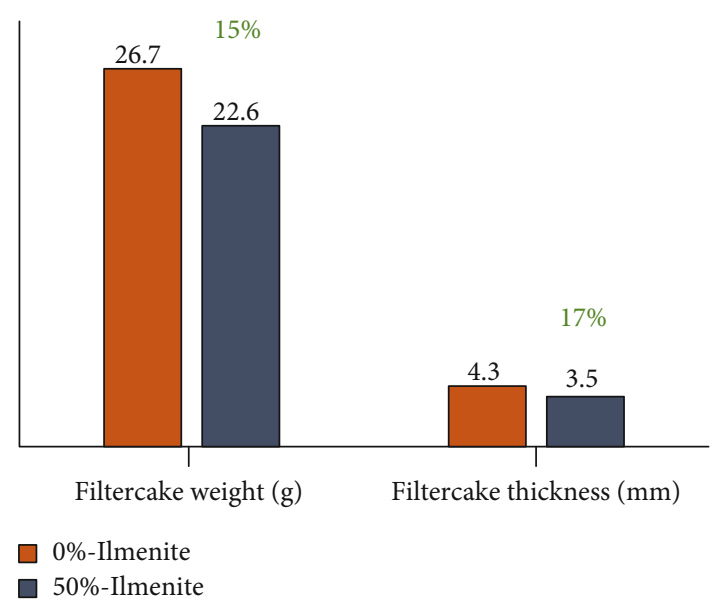

(b)

Figure 8: Effect of adding ilmenite on (a) filtration volume and (b) filter cake weight and thickness.

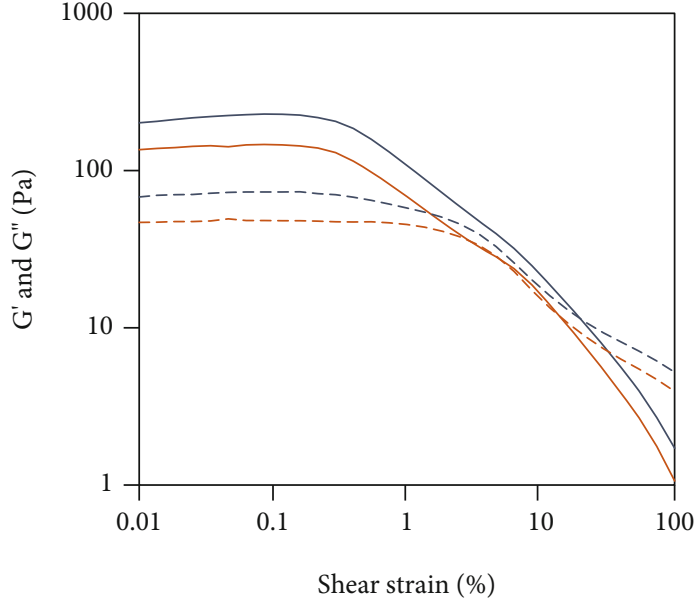

(a)

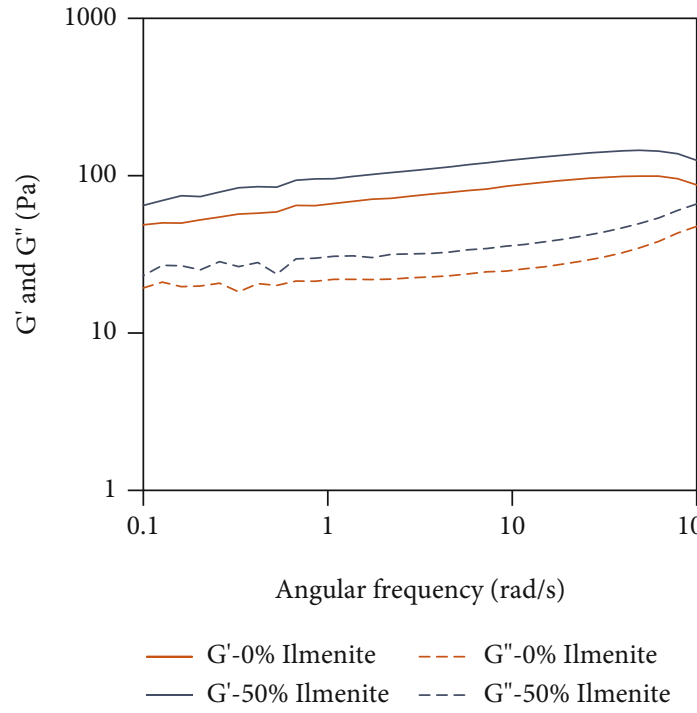

(b)

Figure 9: Results of (a) oscillatory amplitude test and (b) frequency sweep test.

sagging in nonaqueous mud is observed at mud density greater or equal to $14 \mathrm{ppg}$ and temperature higher than or equal to $350^{\circ} \mathrm{F}$; therefore, reducing the density may help in mitigating the sagging occurrence; however, at highpressure applications, it is necessary to assure density maintaining the required hydrostatic pressure. On the other hand, the emulsion stability of the mud was improved upon the addition of $50 \%$ ilmenite, as the electrical stability was increased from 551 to 574 volts. This increment in electrical stability is attributed to the less conductivity of ilmenite compared to hematite. Figure 6 presents the mud weight and electrical stability values for the base hematite and the $50 \%$ ilmenite content at ambient conditions.
3.4. Rheology Tests. The rheology measurements at $350^{\circ} \mathrm{F}$ indicated that using $50 \%$ of ilmenite increased the yield point (YP) significantly by $50 \%$ from 16 to $24 \mathrm{lb} / 100 \mathrm{ft}^{2}$ with inconsiderable impact on plastic viscosity (PV) as it raised from 37 to $38 \mathrm{cP}$ (Figure $7(\mathrm{a})$ ). Therefore, the YP/PV ratio was improved by $46 \%$, indicating an enhancement in mud stability and better hole cleaning practice without a need for additional pressure to circulate the mud $[49,50]$.

Also, the 50\% ilmenite content enhanced the gel strength values at 10 seconds, 10 minutes, and 30 minutes and resulted in flat rheology (Figure 7(b)) because it increases the shear stress at a low shear rate, assigning lower sagging and better suspension and gelling performance. 
3.5. Filtration Performance. The HP/HT filtration experiment at $350^{\circ} \mathrm{F}$ and 500 psi showed an enhancement in filtration characteristics when using $50 \%$ ilmenite over the purehematite mud. The filtrated volume was $6.5 \mathrm{~cm}^{3}$ compared to $8.2 \mathrm{~cm}^{3}$ for base mud which corresponds to a $21 \%$ enhancement, as depicted in Figure 8(a). Also, the composed filter cake with the mixture had weight and thickness of $22.6 \mathrm{~g}$ and $3.5 \mathrm{~mm}$ which were less than the $26.7 \mathrm{~g}$ and $4.3 \mathrm{~mm}$ for the base hematite filter cake by 15 and $17 \%$, respectively (Figure $8(\mathrm{~b})$ ). The features of ilmenite particles and improvement in rheology led to a fast plugging mechanism and decreased the filtrated volume and solid invasion as well. Moreover, the reduced filter cake thickness helps in mitigating the pipe sticking and eases the removal process. Since the practical filter cake is characterized as thin, fastforming, impermeable, and easy to remove, the resulting less filtrated volume, cake thickness, and weight give indications on the enhancement of filtration behaviour. However, evaluating the porosity and permeability is recommended to be considered for future work.

3.6. Viscoelasticity Behaviour. The results of the amplitude sweep test indicated an increment on $G^{\prime}$ and $G^{\prime \prime}$ values upon inclusion addition with predominance of $G^{\prime}$ at low shear rates; also, the linear viscoelastic range was extended as shown in Figure 9(a). As a result, the properties move towards better elasticity, sag resistance, and solid-like behaviour. Moreover, the results of the frequency test displayed in Figure 9(b) showed that the elasticity of the inner structure and mud stability goes hand in hand with the higher $G^{\prime}$ values, which confirmed the enhanced viscoelasticity behaviour of the $50 \%$ ilmenite formulation.

\section{Conclusions}

A comprehensive experimental study was conducted to investigate the influence of ilmenite inclusion towards solving the sag problems that are associated with the application of hematite-based invert emulsion mud at HP/HT and to determine the optimum mixing percentage. The key mud properties were measured and analyzed. The outcomes can be concluded as follows:

(i) Adding 50\% of fine particles of ilmenite fulfilled the hematite sagging avoidance in both static and dynamic conditions

(ii) The less specific gravity of ilmenite resulted in mud's density reduction by $4 \%$ with the recommended mixture of weighting agents, whereas the electrical stability was enhanced from 551 to 574 volts due to the relatively lower ilmenite's conductivity

(iii) Adding the $50 \%$ ilmenite raised the YP by $50 \%$ with only $1 \mathrm{cP}$ increment in $\mathrm{PV}$, enhancing the $\mathrm{YP} / \mathrm{PV}$ ratio by $46 \%$ indicating better fluid stability and hole cleaning without a need for additional pumping pressure for mud circulation (iv) The ilmenite improved the gelling strength and suspension capacity with a result of flat rheology

(v) The filtration behaviour of the mud with 50\% ilmenite was enhanced compared to blank hematite as it resulted in a $21 \%$ drop in filtrated volume with 15 and $17 \%$ improvement in weight and thickness of filter cake

\section{Data Availability}

All the data are included in the manuscript.

\section{Conflicts of Interest}

The authors declare that there is no conflict of interest regarding the publication of this paper.

\section{Acknowledgments}

The authors would like to thank King Fahd University of Petroleum and Minerals (KFUPM) for employing its resources in conducting this work.

\section{References}

[1] G. R. Caenn, R. Darley, and H. Gray, Composition and Properties of Drilling and Completion Fluids, Elsevier, 7th ed. edition, 2016.

[2] G. R. Gray and F. S. Young, "25 years of drilling technology - a review of significant accomplishments," Journal of Petroleum Technology, vol. 25, no. 12, pp. 1347-1354, 1973.

[3] A. Ahmed, A. Alsaihati, and S. Elkatatny, "An overview of the common water-based formulations used for drilling onshore gas wells in the middle east," Arabian Journal for Science and Engineering, vol. 46, no. 7, pp. 6867-6877, 2020.

[4] S. N. Shah, N. H. Shanker, and C. C. Ogugbue, "Future challenges of drilling fluids and their rheological measurements," in AADE Drilling Fluids Conference and Exhibition, Houston, Texas, 2010.

[5] J. M. Davison, M. Jones, C. E. Shuchart, and C. Gerard, "Oilbased muds for reservoir drilling: their performance and cleanup characteristics," SPE Drilling and Completion, vol. 16, no. 2, pp. 127-134, 2001.

[6] R. L. Peresich, B. R. Burrell, and G. M. Prentice, "Development and field trial of a biodegradable invert emulsion fluid," in SPE/IADC Drilling Conference, Amsterdam, Netherlands, 1991.

[7] S. Basfar, A. Ahmed, and S. Elkatatny, "Stability enhancing of water-based drilling fluid at high pressure high temperature," Arabian Journal for Science and Engineering, vol. 46, no. 7, pp. 6895-6901, 2021.

[8] P. A. Bern, E. van Oort, B. Neustadt et al., "Barite sag: measurement, modeling, and management," SPE Drilling and Completion, vol. 15, no. 1, pp. 25-30, 2000.

[9] M. R. Amighi and K. Shahbazi, "Effective ways to avoid barite sag and technologies to predict sag in HPHT and deviated wells," in SPE Deep Gas Conference and Exhibition, Manama, Bahrain, 2010.

[10] P. M. Hanson, T. K. Trigg, G. Rachal, and M. Zamora, "Investigation of barite 'sag' in weighted drilling fluids in highly 
deviated wells," in SPE Annual Technical Conference and Exhibition, New Orleans, Louisiana, 1990.

[11] T. H. Omland, A. Saasen, C. Van Der Zwaag, and P. A. Amundsen, "The effect of weighting material sag on drilling operation efficiency," in SPE Asia Pacific Oil \& Gas Conference and Exhibition, Jakarta, Indonesia, 2007.

[12] P. A. Bern, M. Zamora, K. S. Slater, and P. J. Hearn, "The influence of drilling variables on barite sag," in SPE Annual Technical Conference and Exhibition, Denver, Colorado, 1996.

[13] M. N. J. Al-Awad and A. O. Al-Qasabi, "Characterization and testing of Saudi barite for potential use in drilling operations," Journal of King Saud University-Engineering Sciences, vol. 13, no. 2, pp. 287-298, 2001.

[14] D. Pozebon, E. C. Lima, S. M. Maia, and J. M. G. Fachel, "Heavy metals contribution of non-aqueous fluids used in offshore oil drilling," Fuel, vol. 84, no. 1, pp. 53-61, 2005.

[15] A. S. Al-Yami and H. A. Nasr-El-Din, "An innovative manganese tetroxide/KCl water-based drill-in fluid for HT/HP wells," in SPE Annual Technical Conference and Exhibition, Anaheim, CA, USA, 2007.

[16] N. V. Boyou, I. Ismail, W. R. Wan Sulaiman et al., "Experimental investigation of hole cleaning in directional drilling by using nano-enhanced water-based drilling fluids," Journal of Petroleum Science and Engineering, vol. 176, pp. 220-231, 2019.

[17] A. Mohamed, S. Basfar, S. Elkatatny, and A. Al-Majed, "Prevention of barite sag in oil-based drilling fluids using a mixture of barite and ilmenite as weighting material," Sustainability, vol. 11, no. 20, p. 5617, 2019.

[18] W. Dye, T. Hemphill, W. Gusler, and G. Mullen, "Correlation of ultra-low shear rate viscosity and dynamic barite sag in invert-emulsion drilling fluids," in SPE Annual Technical Conference and Exhibition, Houston Texas, 1999.

[19] R. Yao, G. Jiang, W. Li, T. Deng, and H. Zhang, "Effect of water-based drilling fluid components on filter cake structure," Powder Technoogy, vol. 262, pp. 51-61, 2014.

[20] D. Menzel, "A new weighting material for drilling fluids based on synthetic iron oxide," in Fall Meeting of the Society of Petroleum Engineers of AIME, Las Vegas, Nevada, 1973.

[21] K. Rajendran, S. Sen, G. Suja, S. L. Senthil, and T. V. Kumar, "Evaluation of cytotoxicity of hematite nanoparticles in bacteria and human cell lines," Colloids and Surfaces B: Biointerfaces, vol. 157, pp. 101-109, 2017.

[22] A. D. Scharf and R. D. Watts, "Itabirite: an alternative weighting material for heavy oil-base muds," in SPE Annual Technical Conference and Exhibition, Houston, 1984.

[23] J. Tovar, Z. Rodriguez, F. Quiroga et al., "ORIMATITA ${ }^{\circledR}$. An improved hematite for drilling fluids," in SPE Latin America and Caribbean Petroleum Engineering Conference, Caracas, 1999.

[24] A. Tehrani, A. Cliffe, M. H. Hodder et al., "Alternative drilling fluid weighting agents: a comprehensive study on ilmenite and hematite," in IADC/SPE Drilling Conference and Exhibition, Dallas, TX, USA, 2014.

[25] B. S. Bageri, H. Gamal, S. Elkatatny, and S. Patil, "Effect of different weighting agents on drilling fluids and filter cake properties in sandstone formations," ACS Omega, vol. 6, no. 24, pp. 16176-16186, 2021.

[26] E. Haaland, G. Pettersen, and B. Tuntland, "Testing of iron oxides as weight materials for drilling muds," SPE Journal, vol. 1, pp. 1-15, 1976.
[27] G. Quercia, R. Belisario, and R. Rengifo, "Reduction of erosion rate by particle size distribution (PSD) modification of hematite as weighting agent for oil based drilling fluids," Wear, vol. 266, no. 11-12, pp. 1229-1236, 2009.

[28] M. Al-Bagoury, "Micronized ilmenite - a non-damaging \& amp; non-sagging new weight material for drilling fluids," in SPE Bergen One Day Seminar, Bergen, Norway, April, 2014.

[29] O. Mahmoud, H. A. Nasr-El-Din, Z. Vryzas, and V. C. Kelessidis, "Nanoparticle-based drilling fluids for minimizing formation damage in HP/HT applications," in SPE International Conference and Exhibition on Formation Damage Control, Lafayette, Louisiana, USA, 2016.

[30] J. Xiao, H. A. Nasr-Ei-din, and M. Al-Bagoury, "Evaluation of micronized ilmenite as a weighting material in oil-based drilling fluids for HPHT applications," in SPE European Formation Damage Conference and Exhibition, Noordwijk, The Netherlands, 2013.

[31] A. K. Mohamed, S. A. Elkatatny, M. A. Mahmoud, R. A. Shawabkeh, and A. A. Al-Majed, "The evaluation of micronized barite as a weighting material for completing HPHT wells," in SPE Middle East Oil \& Gas Show and Conference, Manama, Kingdom of Bahrain, 2017.

[32] J. Nasser, A. Jesil, T. Mohiuddin, M. A. Ruqeshi, G. Devi, and S. Mohataram, "Experimental investigation of drilling fluid performance as nanoparticles," World Journal of Nano Science and Engineering, vol. 3, no. 3, pp. 57-61, 2013.

[33] T. M. Madkour, S. Fadl, M. M. Dardir, and M. A. Mekewi, "High performance nature of biodegradable polymeric nanocomposites for oil-well drilling fluids," Egyptian Journal of Petroleum, vol. 25, no. 2, pp. 281-291, 2016.

[34] S. Agarwal, P. Tran, Y. Soong, D. Martello, and R. K. Gupta, "Flow behaviour of nanoparticle stabilized drilling fluids and effect on high temperature aging," in $A A D E$ National Technical Conference and Exhibition, Houston, Texas, USA, 2011.

[35] O. Contreras, M. Alsaba, G. Hareland, M. Husein, and R. Nygaard, "Effect on fracture pressure by adding ironbased and calcium-based nanoparticles to a nonaqueous drilling fluid for permeable formations," Journal of Energy Resources Technology, vol. 138, no. 3, 2016.

[36] O. Contreras, G. Hareland, M. Husein, R. Nygaard, and M. Alsaba, "Experimental investigation on wellbore strengthening in shales by means of nanoparticle-based drilling fluids," in SPE Annual Technical Conference and Exhibition, Amsterdam, The Netherlands, 2014.

[37] O. Contreras, G. Hareland, M. Husein, R. Nygaard, and M. Alsaba, "Wellbore strengthening in sandstones by means of nanoparticle-based drilling fluids," in SPE Deepwater Drilling and Completions Conference, Galveston, Texas, USA, 2014.

[38] S. Basfar and S. Elkatatny, "Prevention of hematite settling using synthetic layered silicate while drilling high-pressure wells," Arabian Journal of Geosciences, vol. 13, no. 12, p. 459, 2020.

[39] A. Ahmed, S. Basfar, S. Elkatatny, and R. Gajbhiye, "Enhancing hematite-based invert emulsion mud stability at highpressure high-temperature wells," ACS Omega, vol. 5, no. 50, pp. 32689-32696, 2020.

[40] A. Ahmed, S. Basfar, and S. Elkatatny, "Sagging prevention for hematite-based invert emulsion mud," Journal of Energy Resources Technology, vol. 144, no. 7, 2022. 
[41] A. Ahmed, S. Basfar, T. I. Solling, and S. Elkatatny, "Prevention of hematite settling in water-based mud at high pressure and high temperature," ACS Omega, vol. 6, no. 36, pp. 23607-23613, 2021.

[42] S. M. Elkatatny, H. A. Nasr-El-Din, and M. Al-Bagoury, "Evaluation of micronized ilmenite as weighting material in waterbased drilling fluids for HPHT applications," in SPE Kuwait international petroleum conference and exhibition, Kuwait City, Kuwait, 2012.

[43] S. Basfar, A. Mohamed, S. Elkatatny, and A. Al-Majed, "A combined barite-ilmenite weighting material to prevent barite sag in water-based drilling fluid," Materials, vol. 12, no. 12, p. 1945, 2019.

[44] S. Basfar, A. Ahmed, T. I. Solling, and S. Elkatatny, "Using manganese tetroxide for hematite settling prevention in water-based mud," Arabian Journal for Science and Engineering, vol. 2021, article 34, 2021.

[45] J. Maxey, "Rheological analysis of static and dynamic sag in drilling fluids," Annual Transactions of the Nordic Rheology Society, vol. 15, 2007.

[46] C. Aldea, F. B. Growcock, L. J. Lee, J. E. Friedheim, and E. Van Oort, "Prevention of dynamic sag in deepwater invert emulsion fluids," in AADE National Drilling Conference, Houston, Texas, 2001.

[47] L. L. Yan, J. H. Wang, X. G. Xu, J. Feng, H. J. Liang, and X. N. Xing, "Study on erosive and magnetic effects of weighting agent in a high density water-based drilling fluid," in Offshore technology conference, Kuala Lumpur, Malaysia,, 2014.

[48] Z. AlAbdullatif, A. Al-Yami, V. Wagle, A. Bubshait, and A. AlSafran, "Development of new kill fluids with minimum sagging problems for high pressure Jilh formation in Saudi Arabia," in Abu Dhabi International Petroleum Exhibition and Conference, Abu Dhabi, UAE, 2014.

[49] G. V. Chilingarian, E. Alp, R. Caenn et al., "Drilling fluid evaluation using yield point-plastic viscosity correlation," Energy Sources, vol. 8, no. 2-3, pp. 233-244, 1986.

[50] S. M. Hussaini and J. J. Azar, "Experimental study of drilled cuttings transport using common drilling muds," Society of Petroleum Engineers Journal, vol. 23, no. 1, pp. 11-20, 1983. 